\title{
Effect of Subsequent Dilute Acid and Enzymatic Hydrolysis on Reducing Sugar Production from Sugarcane Bagasse and Spent Citronella Biomass
}

\author{
Robinson Timung, ${ }^{1}$ Narendra Naik Deshavath, ${ }^{2}$ \\ Vaibhav V. Goud, ${ }^{1,2}$ and Venkata V. Dasu ${ }^{2,3}$ \\ ${ }^{1}$ Department of Chemical Engineering, Indian Institute of Technology Guwahati, Assam 781039, India \\ ${ }^{2}$ Center for Environment, Indian Institute of Technology Guwahati, Assam 781039, India \\ ${ }^{3}$ Department of Biosciences and Bioengineering, Indian Institute of Technology Guwahati, Assam 781039, India \\ Correspondence should be addressed to Vaibhav V. Goud; vvgoud@iitg.ernet.in
}

Received 31 March 2016; Revised 27 June 2016; Accepted 30 June 2016

Academic Editor: S. Venkata Mohan

Copyright ( 2016 Robinson Timung et al. This is an open access article distributed under the Creative Commons Attribution License, which permits unrestricted use, distribution, and reproduction in any medium, provided the original work is properly cited.

\begin{abstract}
This work was aimed at investigating the effect of process parameters on dilute acid pretreatment and enzymatic hydrolysis of spent citronella biomass (after citronella oil extraction) and sugarcane bagasse on total reducing sugar (TRS) yield. In acid pretreatment, the parameters studied were acid concentration, temperature, and time. At the optimized condition $\left(0.1 \mathrm{M} \mathrm{H}_{2} \mathrm{SO}_{4}\right.$, $120^{\circ} \mathrm{C}$, and $120 \mathrm{~min}$ ), maximum TRS obtained was $452.27 \mathrm{mg} \cdot \mathrm{g}^{-1}$ and $487.50 \mathrm{mg} \cdot \mathrm{g}^{-1}$ for bagasse and citronella, respectively. Enzymatic hydrolysis of the pretreated biomass using Trichoderma reesei 26291 showed maximum TRS yield of $226.99 \mathrm{mg} \cdot \mathrm{g}^{-1}$ for citronella and $282.85 \mathrm{mg} \cdot \mathrm{g}^{-1}$ for bagasse at $10 \mathrm{FPU}, 50^{\circ} \mathrm{C}$, and $48 \mathrm{hr}$. The maximum crystallinity index (CI) of bagasse and citronella after acid pretreatment obtained from X-ray diffraction analysis was $64.41 \%$ and $56.18 \%$, respectively. Decreased CI after enzymatic hydrolysis process to $37.28 \%$ and $34.16 \%$ for bagasse and citronella, respectively, revealed effective conversion of crystalline cellulose to glucose. SEM analysis of the untreated and treated biomass revealed significant hydrolysis of holocellulose and disruption of lignin.
\end{abstract}

\section{Introduction}

Lignocellulosic biomass remains one of the most promising renewable feedstocks for the production of bioenergy and biochemicals as it is available in abundance, economical, and eco-friendly. The technologies required for production of fuels from biomass are less capital-intensive than those for fossil fuels. Annually, about 220-billion-ton (oven-dried) biomass availability is being considered as the world's largest sustainable energy resource [1]. Additionally, aromatic spent biomasses such as Citronella and Mentha are the most abundant and underutilized biological resources. India alone produces more than 6.0 million tons per annum of aromatic spent biomass [2]. Lignocellulosic biomass contains varying composition of hemicellulose (20-40 wt\%), cellulose (40$50 \mathrm{wt} \%)$, and lignin (15-30 wt\%), associated with each other in a heteromatrix to different degrees depending on the source, species, and type of biomass [3-5]. Besides having high calorific value, ideal biomass for bioenergy production should contain high cellulose and hemicellulose. Sugarcane bagasse is a potential feedstock due to its high growth rate and high content of holocellulose. Rolz et al. reported 30\% hemicellulose, $28.5 \%$ cellulose, and $11.1 \%$ lignin in java citronella [6]. On the other hand, sugarcane bagasse contains $32-43 \%$ cellulose, $19-34 \%$ hemicellulose, and $25-32 \%$ insoluble lignin [7-9]. Lignocellulosic materials can be converted into liquid and gaseous products such as ethanol, butanol, hydrogen, and carbon dioxide, respectively. The conversion of lignocellulosic biomass to biofuels through sugar platform process involves a pretreatment step to enhance enzymatic hydrolysis of holocellulose to their constituent sugars, fermentation of pentose and hexose sugars, and downstream processing. 
The efficiency of conversion of biomass to total reducing sugars (TRS) depends on the choice of biomass and pretreatment technique employed. An ideal pretreatment of biomass should have the objectives of reducing polyglycan chain length, shrinking recalcitrance of substrate to enzymatic hydrolysis, and avoiding the sugar degradation and formation of fermentation inhibitors. Various types of pretreatment such as chemical (acid, alkali, and organosolv), physical (ultrasound, milling, and comminution), physicochemical (steam explosion, AFEX, and liquid hot water), and biological (using microorganisms such as fungi and bacteria) pretreatment methods have been practiced and others are still in development [10]. The comparison of pretreatment methods is difficult due to the fact that every individual method has its own advantages and disadvantages. It also involves different processing and capital investment, waste treatment systems, and chemical recycling [11]. Chemical pretreatments require recovery of corrosive chemicals and hydrolysate neutralization prior to fermentation, whereas physical treatments require high energy and hence are not cost-effective. Generally, acid pretreatment are practiced either at low concentration of acid at high temperature or at high concentration of acid at low temperature [12]. At high acid concentration, the hydrogen bonding of the cellulose chains gets disrupted reducing the crystallinity of the cellulose to a relatively amorphous state and releasing very less glucose [13]. Concentrated acid hydrolysis is not preferred due to its high corrosiveness, hence being not environmentally and economically viable [14]. Dilute acid (DA) hydrolysis is a more established method and provides less probability of sugar degradation to inhibitors such as 5-HMF or furfural but requires more time and higher temperature to increase the reaction rate for sugar release [15]. DA pretreatment mostly depolymerizes the hemicellulose, which enhance the cellulose digestibility during the enzymatic hydrolysis [16-18]. Different acids like sulfuric acid, phosphoric acid, nitric acid, hydrochloric acid, and so forth have been evaluated, but sulfuric acid has been commonly used for biomass pretreatment $[19,20]$. A typical DA hydrolysis process follows the acid concentration range of $1-6 \%$, temperature range of $100-200^{\circ} \mathrm{C}$, and reaction time of up to $300 \mathrm{~min}$. Enzymatic hydrolysis of pretreated lignocellulosic biomass is a promising step to obtain the high carbohydrates yield. Hence, the pretreatment process remains a vital step to provide suitable condition for enzymatic hydrolysis. Enzymatic hydrolysis at mild condition results in negligible by-products formation with high sugar yields.

Since limited reports are available in the literature on DA hydrolysis of spent biomass of the aromatic plant, hence this work is an endeavor to evaluate the effect of subsequent dilute acid and enzymatic hydrolysis on production of TRS from spent biomass of java citronella compared with standard lignocellulosic biomass (i.e., sugarcane bagasse). Spent citronella biomass has been chosen due to its abundance as raw material in the north eastern part of India. Structural changes in native and pretreated biomass samples were characterized using X-ray diffraction and scanning electron microscope (SEM). Results of the study revealed that the spent aromatic plants biomass could act as a potential lignocellulosic material for biofuel (bioethanol) production.

\section{Materials and Methods}

2.1. Feed Stock. Spent citronella biomass (after essential oil extraction) and sugarcane bagasse obtained from local farms of Karbi Anglong and Guwahati, Assam (India) were dried, chopped into small pieces, ground, sieved to $1 \mathrm{~mm}$ sizes using 16 BSS mesh screen, and then stored in a zipped lock plastic bag at ambient temperature (approx. $25^{\circ} \mathrm{C}$ ) until use. All the chemicals used for the study were of analytical grade and purchased from M/s Himedia and M/s Merck India Pvt. Ltd.

\subsection{Characterization of Biomass}

2.2.1. Determination of Extractives. The amount of extractives in the biomass (citronella and bagasse) was estimated by NREL protocol using Soxhlet extraction apparatus through extraction thimbles. Sequential extraction, $n$-hexane followed by ethanol (95\%) and distilled water, was performed according to the procedure reported elsewhere [21-23]. In order to remove the nonpolar compounds, biomass was extracted with hexane to separate nonpolar lipids, hydrocarbon compounds, and terpenoids and so forth. The raffinate biomass was further extracted with ethanol to remove waxes, chlorophyll, sterol, and so forth. The final raffinate biomass was extracted using Millipore water to remove nonstructural carbohydrates and inorganic materials. Thermogravimetric analysis (TGA) of the final raffinate was performed to estimate hemicellulose, cellulose, and lignin content of the individual biomass.

\subsubsection{TGA Analysis for Hemicellulose, Cellulose, and Lignin} Content. Thermogravimetric analysis is a widely used technique to study the temperature assisted degradation profile of a material and the kinetics of its thermal decomposition. Several reports in the literature demonstrated that degradation of biomass samples follows the first-order reaction kinetics and hence the concentration of individual constituents in a biomass is directly proportional to the degradation rate [35, 36]. TGA study is also being used to estimate approximate weight percentage of the cellulose, hemicellulose, and lignin in biomass samples. Hence, to determine the major chemical composition, namely, hemicellulose, cellulose, and lignin content in the sample biomass, TG analysis was performed using METTLER TOLEDO, Switzerland (Model number TGA $851 \mathrm{e} / \mathrm{LF} / 1100$ ) at the heating rate of $10^{\circ} \mathrm{C} \cdot \mathrm{min}^{-1}$ from $30^{\circ} \mathrm{C}$ to $700^{\circ} \mathrm{C}$ under nitrogen atmosphere according to the procedure followed by Naik et al. and Carrier et al. [22, 37]. The continuous records of weight loss versus temperature data were obtained and analyzed through the software (STAR) provided by the manufacturer of TGA.

2.2.3. Calorific Value Determination. The calorific value of biomass was determined using static bomb calorimeter: sealed parr 1108 according to the protocol reported by Naik et al. [22]. The biomass sample pellets approximately weighing $1 \mathrm{~g}$ each were put in contact with the platinum wire attached with cotton thread which was placed in the ignition port. Approximately, 1 liter of Millipore water was poured 
into the bomb and then filled with oxygen to a consistent pressure between 20 and $30 \mathrm{~atm}$. The bomb calorimeter was submerged in Millipore water and the calorimeter jacket was maintained at $25^{\circ} \mathrm{C}$ by circulating water. In the isothermal jacket, calorimeter was placed with $10 \mathrm{~mm}$ air gap between surfaces. The ignition energy when discharged from about $\sim 40 \mathrm{~V}$ platinum wire was evaluated from the change in potential across a 1256 or $2900 \mathrm{mF}$ capacitor.

2.3. Acid Hydrolysis of Biomass Samples. The biomass samples were treated with dilute sulfuric acid to hydrolyse hemicellulose and increase the accessibility of cellulose. The biomass samples were treated with $0.1,0.3,0.5,0.7$, and $0.9 \mathrm{M} \mathrm{H}_{2} \mathrm{SO}_{4}$ at solid to liquid ratio of $1: 10\left(\mathrm{w} \cdot \mathrm{v}^{-1}\right)$, temperature range of $80-120^{\circ} \mathrm{C}\left(20^{\circ} \mathrm{C}\right.$ interval), and reaction time of $120 \mathrm{~min}$ (30 min interval). Experiments which require temperature up to $100^{\circ} \mathrm{C}$ were performed in shaker water bath (Lab Tech); however, higher temperature experiments (i.e., $120^{\circ} \mathrm{C}$ ) were carried out in an autoclave at $15 \mathrm{lbs}$ pressure. Utmost care was taken to ensure that the biomass was completely wetted by mixing for 5-10 min before the reaction. At every $30 \mathrm{~min}$ interval, reaction mixture was allowed to cool to room temperature and $0.1 \mathrm{~mL}$ of hydrolysate was pipetted out to estimate the concentration of TRS using dinitrosalicylic (DNS) acid method [38]. Optimum sugar yield samples were neutralized using $1 \mathrm{M} \mathrm{NaOH}$ solution and further washed with distilled water for the removal of salts and other impurities. The substrate was then air-dried at room temperature and later subjected to enzymatic hydrolysis using commercial cellulase solution Celluclast ${ }^{\circledR} 1.5$ L. Drying of the substrate at high temperature was avoided as it might cause irreversible pore collapse [24, 39, 40].

2.3.1. XRD Analysis. The biomass crystallinity was estimated using wide angle X-ray diffractometer (Bruker D8 Advanced $\mathrm{X}$-ray diffraction measurement systems, Japan). The Rigaku miniflex XRD was equipped with $\mathrm{Cu} \mathrm{K} \alpha(\lambda=1.541 \AA)$ radiation settled at $40 \mathrm{KW}$ voltages and $40 \mathrm{~mA}$ current. The diffraction angle $(2 \theta)$ was 10 to $30^{\circ}$ at a scan speed of $1^{\circ} \mathrm{min}^{-1}$ and step size of $0.05^{\circ}$. The crystallinity index (CI) was calculated based on the intensity of amorphous region at $\sim 18.5 \pm 0.05^{\circ}$ of $2 \theta\left(I_{\mathrm{amp}}\right)$ and the maximum intensity obtained from crystalline fraction of 002 lattice plane at $\sim 22.3 \pm 0.1^{\circ}$ of $2 \theta\left(I_{002}\right)$ by using the following $[23,41]$ :

$$
\mathrm{CI}(\%)=\frac{I_{002}-I_{\mathrm{amp}}}{I_{002}} \times 100 .
$$

2.3.2. SEM Analysis. Surface morphology of biomass samples (untreated and hydrolysed (treated) biomass of citronella and bagasse) was qualitatively studied using SEM (LEO, Model 1430vp, Germany). The dried samples were placed on aluminum specimen mount, using conductive carbon tape. Sputter gold coating was performed to prevent charging. All the specimens were examined in SEM under vacuum condition at accelerating voltage of either $7 \mathrm{kV}$ or $8 \mathrm{kV}$ or $10 \mathrm{kV}$.

\section{Results and Discussion}

3.1. Composition Analysis of Biomass. The information about the amount of extractives in the biomass sample helps to estimate exact amount of fermentable sugars present in the biomass. Extractives in biomass consist of nonstructural aromatic compounds, which include volatile oils, chlorophyll, fatty acids, and their esters, waxes, resins, tannins, terpenes, and so forth and can be used further for the production of green chemicals [23]. These are basically polar or nonpolar components which can be extracted using different solvents based on their polarity. To begin, extraction was carried out using $n$-hexane to remove nonpolar compounds such as lipids, hydrocarbons, and terpenes, followed by ethanol as solvent to extract polar compounds such as chlorophyll, waxes, and sterols. The final raffinate biomass was extracted with water to remove the nonstructural sugars and other inorganic compounds. The water extractives were more in both the biomass types compared to ethanol and hexane unveiling the presence of more polar compounds in the biomass samples (Table 1).

Estimation of hemicellulose, cellulose, and lignin, which are the major chemical components of lignocellulosic biomass, is important in order to determine the conversion efficiency of biomass to bioenergy and other valuable chemicals. From the study, it was revealed that citronella has lower cellulose content (28.15\%) than hemicellulose $(32.22 \%)$ with lignin content of $18.78 \%$. On the other hand, bagasse was composed of higher cellulose $(40.15 \%)$ compared to hemicellulose (22.78\%) and lignin (20.81\%).

The estimation of calorific value of the biomass samples revealed that calorific value of citronella $\left(16.98 \mathrm{MJ} \cdot \mathrm{Kg}^{-1}\right)$ was comparable with bagasse $\left(17.20 \mathrm{MJ} \cdot \mathrm{Kg}^{-1}\right)$. Moreover, in the present study, calorific value obtained for both the biomass types closely resembles the literature reported values with other biomass, such as barley straw $\left(15.7 \mathrm{MJ} \cdot \mathrm{Kg}^{-1}\right)$, flax straw (17.0 MJ. $\left.\mathrm{Kg}^{-1}\right)$, and timothy straw (16.7 MJ. Kg $\left.{ }^{-1}\right)$ [22]. Abdullah et al. accounted calorific value of $14.79 \mathrm{MJ} \cdot \mathrm{Kg}^{-1}$ for rice husk and paddy straw $13.74 \mathrm{MJ} \cdot \mathrm{Kg}^{-1}$ [42], whereas Sasmal et al. reported $17.83 \mathrm{MJ} \cdot \mathrm{Kg}^{-1}$ for areca nut husk [23].

3.2. Acid Hydrolysis. The effects of acid $\left(\mathrm{H}_{2} \mathrm{SO}_{4}\right)$ concentration $\left(0.1,0.3,0.5,0.7\right.$, and $\left.0.9 \mathrm{M} \mathrm{H}_{2} \mathrm{SO}_{4}\right)$, reaction time $(30,60,90$, and $120 \mathrm{~min})$, and temperature $(80,100$, and $120^{\circ} \mathrm{C}$ ) on TRS yield of both the biomass types were evaluated individually. Both the biomass types exhibit similar behavior of TRS production within the studied range. The effects of reaction time and $\mathrm{H}_{2} \mathrm{SO}_{4}$ concentration at different temperatures on TRS production for sugarcane bagasse and spent citronella biomass are depicted in Figures 1 and 2, respectively. From the figures, it can be seen that TRS yield increased with an increase in the acid concentrations (0.1$0.9 \mathrm{M})$ and reaction time $(30-120 \mathrm{~min})$ at 80 and $100^{\circ} \mathrm{C}$, but a drop in TRS yield was observed at $120 \mathrm{~min}$ of hydrolysis time and $120^{\circ} \mathrm{C}$, which may be due to the formation of inhibitory products in the hydrolysate (Figures 3 and 4). These degraded products inhibit the growth of microorganisms during the biofuel production. Pentose sugar of 
TABLE 1: Extractives (g) from $100 \mathrm{~g}$ biomass sample.

\begin{tabular}{lccccccc}
\hline Biomass type & Hexane extract & Ethanol extract & Water extract & Hemicellulose & Cellulose & Lignin & Calorific value $\left(\mathrm{MJ} \cdot \mathrm{Kg}^{-1}\right)$ \\
\hline Spent citronella biomass & $3.06 \pm 0.11$ & $1.79 \pm 0.15$ & $6.68 \pm 0.26$ & $32.22 \pm 0.28$ & $28.15 \pm 0.12$ & $18.78 \pm 0.19$ & $16.98 \pm 0.18$ \\
Bagasse & $0.9 \pm 0.3$ & $6.5 \pm 0.3$ & $7.7 \pm 0.4$ & $22.78 \pm 0.2$ & $40.15 \pm 0.3$ & $20.81 \pm 0.2$ & $17.20 \pm 0.18$ \\
\hline
\end{tabular}
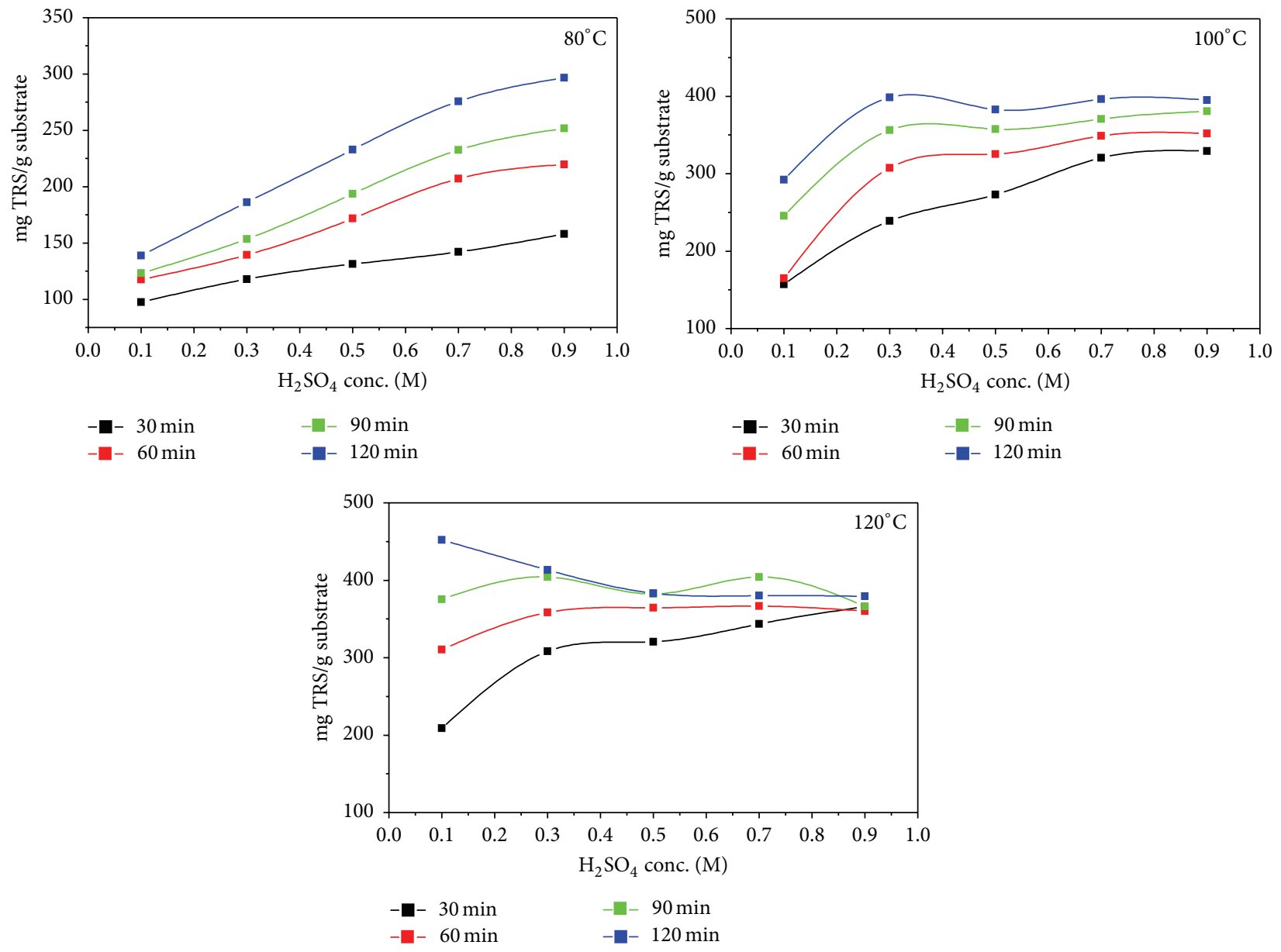

FIGURE 1: Effect of reaction time and $\mathrm{H}_{2} \mathrm{SO}_{4}$ concentration at different temperature on the production of TRS from sugarcane bagasse.

xylose and hexose sugar of glucose are responsible for the formation of fermentative inhibitors known as furfural and 5hydroxymethyl furfural (5-HMF), respectively. The concentration of furfural and 5-HMF may increase with an increase acid concentration, temperature, and time [43-45]. The minimum (97.40 $\mathrm{mg}^{-1} \mathrm{~g}^{-1}$ and $11.98 \mathrm{mg} \cdot \mathrm{g}^{-1}$ ) and maximum (296.64 $\mathrm{mg} \cdot \mathrm{g}^{-1}$ and $274.93 \mathrm{mg} \cdot \mathrm{g}^{-1}$ ) TRS yield were observed at $80^{\circ} \mathrm{C}$ for sugarcane bagasse and spent citronella biomass at $0.1 \mathrm{M}, 30 \mathrm{~min}$, and $0.9 \mathrm{M}, 120 \mathrm{~min}$, respectively, which shows that deformation rate of polymeric carbohydrates of sugarcane bagasse is higher than the spent citronella biomass at $80^{\circ} \mathrm{C}$. On the other hand, during acid hydrolysis of spent citronella biomass, dissolution of hemicellulose yielded more sugars than sugarcane bagasse with increase in the process temperature from 100 to $120^{\circ} \mathrm{C}$. The optimum conditions to attain maximum sugar yield were almost identical for both the biomass types, whereas the reducing sugar yield was comparatively higher in the citronella biomass, which may be due to higher hemicellulose content in citronella compared to sugarcane bagasse. The maximum TRS released from sugarcane bagasse $\left(452.27 \mathrm{mg} \cdot \mathrm{g}^{-1}\right)$ and spent citronella biomass $\left(487.50 \mathrm{mg} \cdot \mathrm{g}^{-1}\right.$ ) was obtained at $30 \mathrm{~min}, 120^{\circ} \mathrm{C}$, and $0.1 \mathrm{M} \mathrm{H}_{2} \mathrm{SO}_{4}$. Considering the total holocellulose content of the substrate, conversion efficiency of polymeric carbohydrates to monomeric sugars was $71.87 \%$ for sugarcane bagasse and $80.75 \%$ for spent citronella biomass. Results of the study revealed that hydrolysis of soft biomass yields more sugars at high temperature and longer residence time but lower acid concentration [46]. Similarly, Rajan and Carrier and Kootstra et al. in their study suggested that increased reaction time, temperature, and acid concentration lead to the formation of fermentative inhibitors like HMF, furfural, formic acid, and acetic acid, which also affects the growth of microbes during the fermentation process and other value added products $[47,48]$. Therefore, in the present study, mild hydrolysis conditions (i.e., sulfuric acid concentration, 

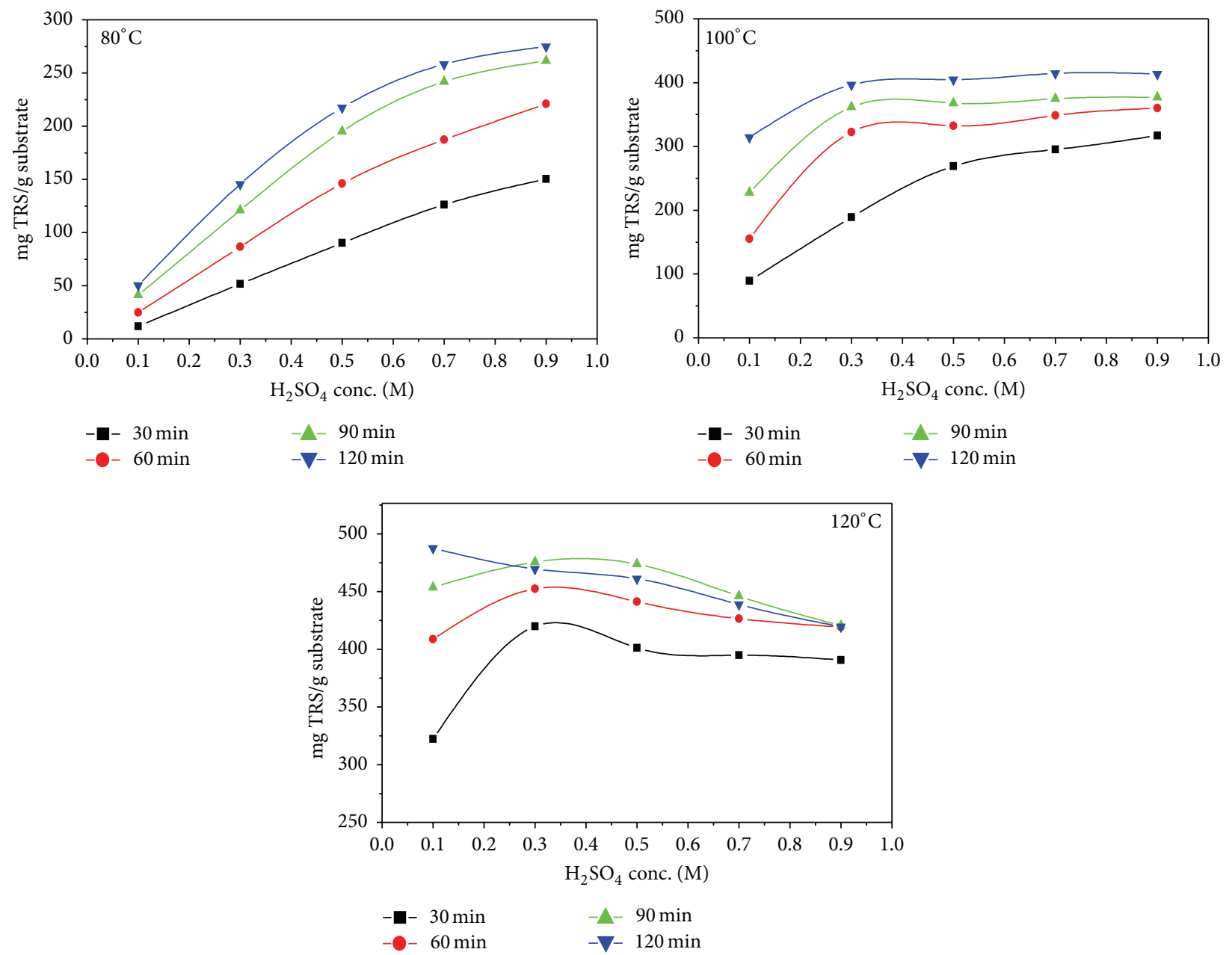

FIGURE 2: Effect of reaction time and $\mathrm{H}_{2} \mathrm{SO}_{4}$ concentration at different temperature on the production of TRS from spent citronella biomass.

$0.1 \mathrm{M}\left(\mathrm{v} \cdot \mathrm{v}^{-1}\right)$; solid to liquid ratio, $1: 10$; reaction time, $30 \mathrm{~min}$; and temperature, $120^{\circ} \mathrm{C}$ ) were preferred to obtain high yield of TRS, because microorganisms generally prefers to grow in the medium containing sugars such as glucose. Moutta et al. reported maximum TRS yield of $56.5 \mathrm{~g} \cdot \mathrm{L}^{-1}$ at $130^{\circ} \mathrm{C}$, $2.9 \% \mathrm{H}_{2} \mathrm{SO}_{4}$, and reaction time of $30 \mathrm{~min}$ during dilute acid hydrolysis of sugarcane leaves straw [25]. On the other hand, Chandel et al. found maximum TRS of $30.29 \mathrm{~g} \cdot \mathrm{L}^{-1}$ in the acid hydrolysis of sugarcane bagasse at optimum condition of $140^{\circ} \mathrm{C}, 2.5 \% \mathrm{HCl}, 30 \mathrm{~min}$, and $1: 10$ solid to liquid ratio [26], whereas Pattra et al. reported TRS of $24.5 \mathrm{~g} \cdot \mathrm{L}^{-1}$ during acid hydrolysis of sugarcane bagasse at the optimal conditions of $0.5 \% \mathrm{H}_{2} \mathrm{SO}_{4}$ and $60 \mathrm{~min}$ hydrolysis time [27]. As discussed in the aforementioned sections, TRS yield obtained in the present study was comparable with reported literature with minimal variations (Table 2). Besides hydrolysis conditions like acid concentration, temperature, and reaction time, the varying yield of TRS might be attributed to factors such as types or species of biomass, particle size, and amount of cellulose, hemicellulose, and lignin content of the biomass. Thus, the experimental range explored in this work furnished the optimum condition as $0.1 \mathrm{M}\left(\mathrm{v} \cdot \mathrm{v}^{-1}\right)$ (approx. $0.6 \%$ $\mathrm{H}_{2} \mathrm{SO}_{4}$ ); solid to liquid ratio, $1: 10$; reaction time, $30 \mathrm{~min}$; and temperature, $120^{\circ} \mathrm{C}$. In the acid hydrolysis (using $\mathrm{H}_{2} \mathrm{SO}_{4}$ ) of sugarcane bagasse, the optimal condition obtained by different researchers closely resembles the optimum condition obtained in the present study: Betancur and Pereira Jr. found optimal condition as $121^{\circ} \mathrm{C}$, solid to liquid ratio $1: 2.8,1.09 \%$ $\mathrm{H}_{2} \mathrm{SO}_{4}$, and $27 \mathrm{~min}$ [28]. On the other hand, Aguilar et al. observed the optimal condition at $122^{\circ} \mathrm{C}, 2 \% \mathrm{H}_{2} \mathrm{SO}_{4}$, and $24 \mathrm{~min}$ [29], whereas Jonglertjunya et al. obtained maximum sugar yield $\left(52 \mathrm{~g} \cdot \mathrm{L}^{-1}\right)$ at $1 \% \mathrm{H}_{2} \mathrm{SO}_{4}, 121^{\circ} \mathrm{C}$, bagasse to solvent ratio $1: 10$, and $60 \mathrm{~min}[30]$.

3.3. Enzymatic Hydrolysis. Pretreatment of biomass is necessary before enzymatic hydrolysis to provide easy accessibility to convert cellulose to glucose and hemicellulose to xylose and arabinose by various types of enzymes. During dilute acid pretreatment, major portion of hemicellulose gets hydrolysed to form its monomeric constituents. The residual biomass may contain major portion of cellulose and minor amount of lignin. As noted earlier, the biomass was pretreated with optimum condition at which maximum TRS yield obtained was subjected to subsequent enzymatic hydrolysis using commercially available cellulase (Celluclast $1.5 \mathrm{~L}$ ) for cellulose conversion. Most of the glucose is released during enzymatic 

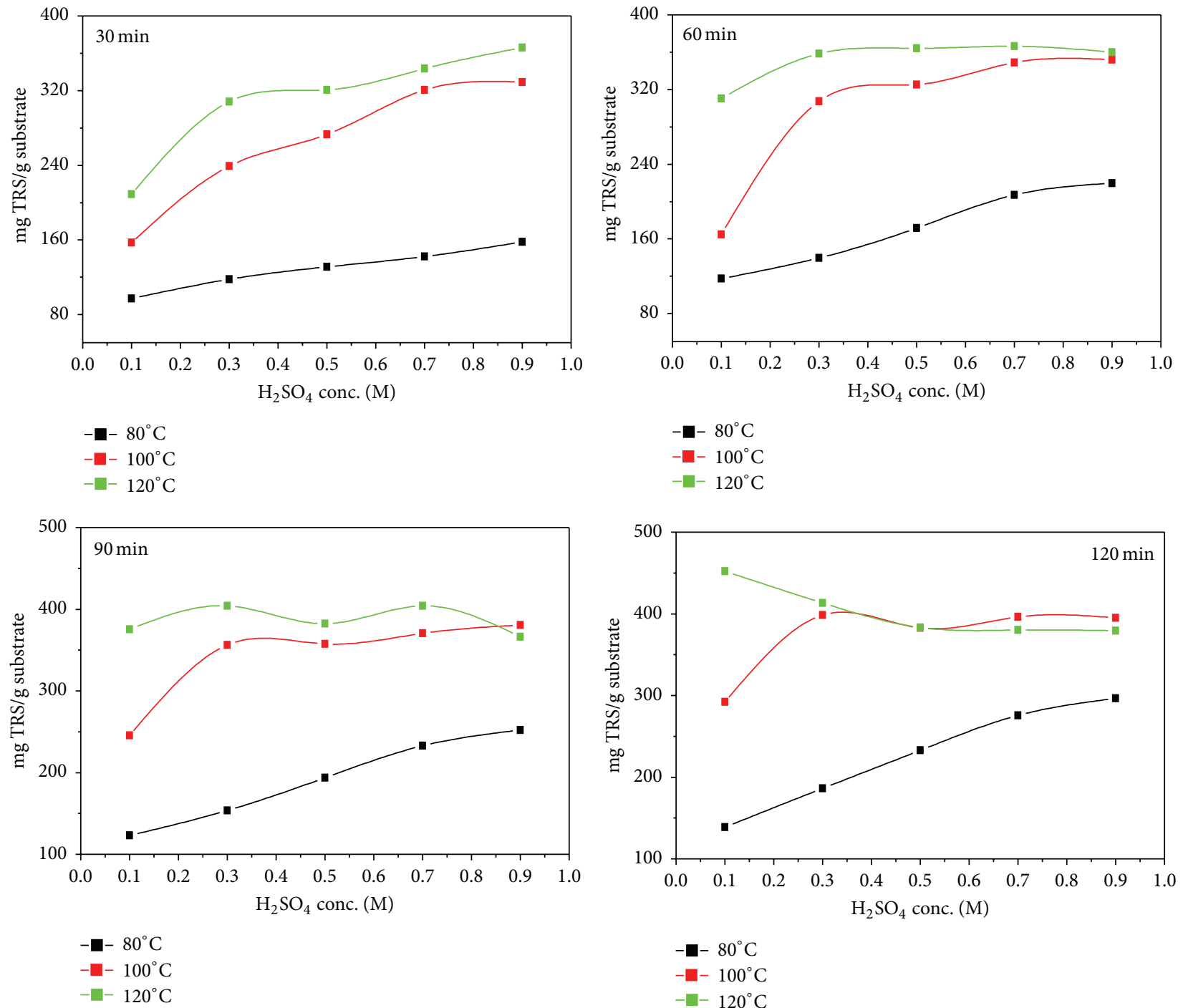

FIGURE 3: Effect of temperature and $\mathrm{H}_{2} \mathrm{SO}_{4}$ concentration at different reaction time on the production of TRS from sugarcane bagasse.

TABLE 2: Comparison of the present study in production of total TRS with reported literature.

\begin{tabular}{|c|c|c|c|}
\hline Biomass source & Reaction conditions & Maximum TRS yield & Reference \\
\hline Sugarcane bagasse & $0.1-0.9 \mathrm{M} \mathrm{H}_{2} \mathrm{SO}_{4}, 80-120^{\circ} \mathrm{C}, 30-120 \mathrm{~min}, \mathrm{~S}: \mathrm{L} ; 1: 10$ & $487.50 \mathrm{mg} \cdot \mathrm{g}^{-1}$ & This study \\
\hline Spent citronella & $0.1-0.9 \mathrm{M} \mathrm{H}_{2} \mathrm{SO}_{4}, 80-120^{\circ} \mathrm{C}, 30-120 \mathrm{~min}, \mathrm{~S}: \mathrm{L} ; 1: 10$ & $452.27 \mathrm{mg} \cdot \mathrm{g}^{-1}$ & This study \\
\hline Sugarcane bagasse & $2.9 \% \mathrm{H}_{2} \mathrm{SO}_{4}, 130^{\circ} \mathrm{C}, 30 \mathrm{~min}, \mathrm{~S}: \mathrm{L} ; 1: 4$ & $58 \mathrm{~g} \cdot \mathrm{L}^{-1}$ of xylose & [24] \\
\hline Sugarcane leaves straw & $0.5-3.5 \% \mathrm{H}_{2} \mathrm{SO}_{4}, 110-130^{\circ} \mathrm{C}, 10-60 \mathrm{~min}, 1: 2-1: 10$ & $56.5 \mathrm{~g} \cdot \mathrm{L}^{-1}$ & [25] \\
\hline Sugarcane bagasse & $0.5-3.5 \% \mathrm{HCl}, 140^{\circ} \mathrm{C}, 30 \mathrm{~min}, \mathrm{~S}: \mathrm{L} ; 1: 10$ & $30.29 \mathrm{~g} \cdot \mathrm{L}^{-1}$ & {$[26]$} \\
\hline Sugarcane bagasse & $0.25-7 \% \mathrm{H}_{2} \mathrm{SO}_{4}, 121^{\circ} \mathrm{C}, 15-240 \mathrm{~min}, \mathrm{~S}: \mathrm{L} ; 1: 1.7$ & $24.5 \mathrm{~g} \cdot \mathrm{L}^{-1}$ & [27] \\
\hline Sugarcane bagasse & $0.5-1.75 \% \mathrm{H}_{2} \mathrm{SO}_{4}, 121^{\circ} \mathrm{C}, 27-93 \mathrm{~min}, \mathrm{~S}: \mathrm{L} ; 1: 1.7-1: 3.3$ & $52 \mathrm{~g} \cdot \mathrm{L}^{-1}$ of xylose & [28] \\
\hline Sugarcane bagasse & $2-6 \% \mathrm{H}_{2} \mathrm{SO}_{4}, 100-128^{\circ} \mathrm{C}, 0-300 \mathrm{~min}, \mathrm{~S}: \mathrm{L} ; 1: 10$ & $21.6 \mathrm{~g} \cdot \mathrm{L}^{-1}$ of xylose & [29] \\
\hline Sugarcane bagasse & $0.25-1.0 \% \mathrm{H}_{2} \mathrm{SO}_{4}, 30-121^{\circ} \mathrm{C}, 15-60 \mathrm{~min}, \mathrm{~S}: \mathrm{L} ; 1: 10-1: 20$ & $52 \mathrm{~g} \cdot \mathrm{L}^{-1}$ & [30] \\
\hline Sugarcane bagasse & $0.25-1.5 \% \mathrm{H}_{2} \mathrm{SO}_{4}, 140-160^{\circ} \mathrm{C}, 15-60 \mathrm{~min}$ & $37.7 \%$ & {$[31]$} \\
\hline Sugarcane bagasse & $10 \% \mathrm{H}_{2} \mathrm{SO}_{4}, 100^{\circ} \mathrm{C}, 0-60 \mathrm{~min}$ & $81.50 \mathrm{~g} \cdot \mathrm{L}^{-1}$ of xylose & [32] \\
\hline Sugarcane tops & $3 \% \mathrm{H}_{2} \mathrm{SO}_{4}, 60 \mathrm{~min}, 25 \% \mathrm{w} / \mathrm{w}$ biomass & $685 \mathrm{mg} \cdot \mathrm{g}^{-1}$ & {$[33]$} \\
\hline Rice hulls & $0.25-1 \% \mathrm{H}_{2} \mathrm{SO}_{4}, 140-180^{\circ} \mathrm{C}, 15-60 \mathrm{~min}$ & $189 \mathrm{mg} \cdot \mathrm{g}^{-1}$ & {$[34]$} \\
\hline
\end{tabular}



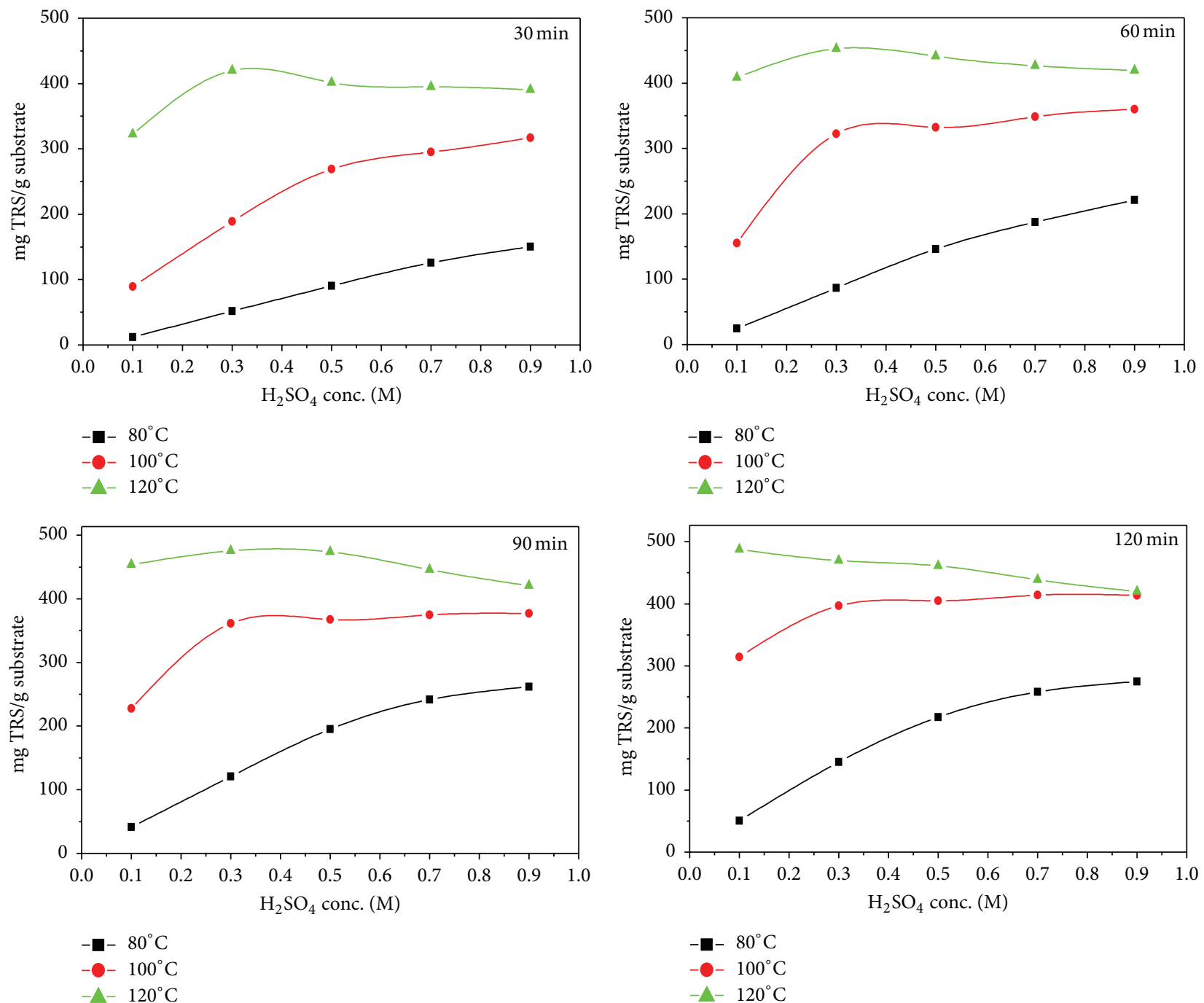

FIGURE 4: Effect of temperature and $\mathrm{H}_{2} \mathrm{SO}_{4}$ concentration at different reaction time on the production of TRS from spent citronella biomass.

hydrolysis [49]. The use of pretreated substrate after washing with water can reduce the concentration of inhibitory products $[41,50]$. In the present work, the maximum TRS yield pretreated biomass was neutralized and water washed before enzymatic hydrolysis. Schematic representation of the overall process has been depicted in Figure 5. The effects of temperature $\left(40-60^{\circ} \mathrm{C}\right)$, reaction time $(24-72 \mathrm{hr})$, and enzyme loading (10-30 FPU.g ${ }^{-1}$ of substrate) on TRS yield were evaluated for both the biomass types. The TRS production increased with time up to $48 \mathrm{hr}$ and thereafter decreased. Similarly, TRS released also decreased with an increase in the temperature from 50 to $60^{\circ} \mathrm{C}$. The maximum TRS released was found to be $226.99 \mathrm{mg} \cdot \mathrm{g}^{-1}$ and $282.85 \mathrm{mg} \cdot \mathrm{g}^{-1}$ for citronella and bagasse, respectively, at $50^{\circ} \mathrm{C}, 48 \mathrm{hr}$, and enzyme loading of $10 \mathrm{FPU} \cdot \mathrm{g}^{-1}$ (Table 3). Rajan and Carrier also reported the highest glucose recovery (89\%) for enzymatic hydrolysis of wheat straw at $48 \mathrm{hr}$ [47]. On the other hand, Sun and Cheng in their study with bermuda grass and rye straw, using $1.5 \%$ sulphuric acid pretreated substrate, found $197.1 \mathrm{mg} \cdot \mathrm{g}^{-1}$ and $229.3 \mathrm{mg} \cdot \mathrm{g}^{-1}$ reducing sugars for enzymatic hydrolysis time of $48 \mathrm{hr}$ [10].
Similarly, Saha et al. $[34,51]$ observed maximum sugar yield of $287 \pm 3 \mathrm{mg} \cdot \mathrm{g}^{-1}$ for rice hull $(60 \%$ yield considering total content of carbohydrate) and $565 \pm 10 \mathrm{mg} \cdot \mathrm{g}^{-1}$ for wheat straw (76\% yield considering total content of carbohydrate). FiletoPèrez et al. in their study obtained $50^{\circ} \mathrm{C}$ as the optimum temperature for hydrolysis of cellulose using enzymes [52]. Enzyme concentration is inversely proportional to FPU; therefore, a decrease in the TRS production was noticed with increase in the enzyme loading from $10 \mathrm{FPU}$ to $30 \mathrm{FPU}$. On the other hand, increase in the reaction temperature $\left(60^{\circ} \mathrm{C}\right)$ decreased the TRS yield, which may be due to the denaturation of cellulase enzyme at higher temperature. In the present study, enzymatic hydrolysis of pretreated biomass showed high TRS yield for bagasse than citronella. This can be attributed to the fact that sugarcane bagasse has higher cellulose conversion efficiency compared to citronella; citronella might contain more lignin compared to sugarcane bagasse after the pretreatment; moreover aliphatic and aromatic constituents of lignin can also hinder the cellulase activity [53]. 
TABLE 3: Effect of temperature, time, and enzyme concentration on production of TRS during enzymatic hydrolysis of citronella and bagasse.

\begin{tabular}{|c|c|c|c|c|c|c|c|}
\hline \multirow{3}{*}{ Temp. $\left({ }^{\circ} \mathrm{C}\right)$} & \multirow{3}{*}{ FPU (IU) } & \multicolumn{6}{|c|}{ TRS (mg.g ${ }^{-1}$ substrate) } \\
\hline & & \multicolumn{2}{|c|}{$24 \mathrm{hr}$} & \multicolumn{2}{|c|}{$48 \mathrm{hr}$} & \multicolumn{2}{|c|}{$72 \mathrm{hr}$} \\
\hline & & Citronella & Bagasse & Citronella & Bagasse & Citronella & Bagasse \\
\hline \multirow{3}{*}{40} & 10 & 134.88 & 181.48 & 178.76 & 212.36 & 174.98 & 204.34 \\
\hline & 20 & 126.77 & 136.32 & 139.83 & 152.76 & 132.95 & 136.93 \\
\hline & 30 & 116.35 & 108.25 & 126.34 & 137.54 & 112.85 & 123.87 \\
\hline \multirow{3}{*}{50} & 10 & 204.56 & 246.96 & 226.99 & 282.85 & 218.81 & 253.89 \\
\hline & 20 & 185.75 & 238.42 & 203.33 & 266.21 & 194.12 & 228.63 \\
\hline & 30 & 163.89 & 232.63 & 174.82 & 248.41 & 169.44 & 216.64 \\
\hline \multirow{3}{*}{60} & 10 & 105.93 & 126.77 & 123.10 & 137.11 & 102.17 & 117.54 \\
\hline & 20 & 84.23 & 92.91 & 102.19 & 109.35 & 83.72 & 96.02 \\
\hline & 30 & 53.26 & 88.28 & 91.61 & 97.23 & 79.94 & 83.48 \\
\hline
\end{tabular}

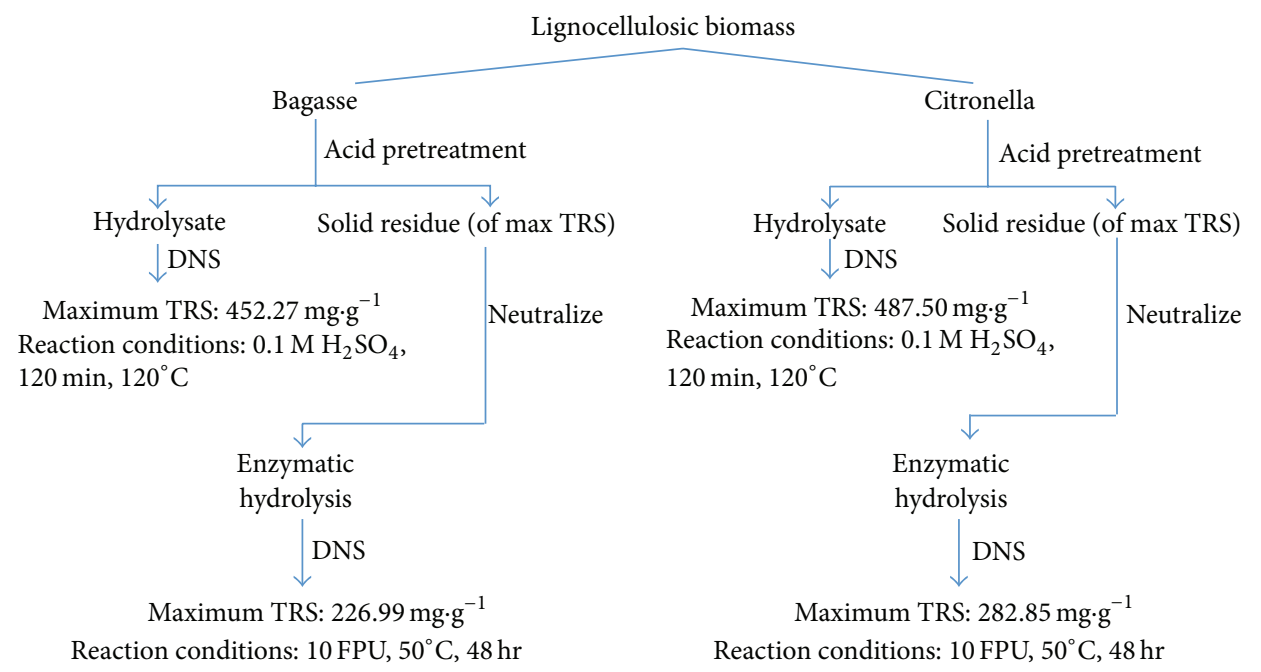

FIGURE 5: Schematic representation of overall methodology and major results.

3.4. Characterization of Residual Biomass Samples. XRD and SEM analysis were used as tools to investigate the structural changes that occurred during the dilute acid pretreatment of both the biomass types. The crystalline structure of biomass is mainly due to the strong hydrogen bonding of cellulose chains and Vander Waals forces of glucose molecules in the cellulose $[22,23]$. The untreated biomass of citronella and bagasse showed crystallinity index (CI) of $32.97 \%$ and $33.15 \%$, respectively. CI of spent citronella biomass (after citronella oil extraction) increased to $34.91 \%$, because of the removal of water extractives during the oil extraction process. The CI of acid treated biomass was found to increase from $48.04 \%$ to $56.18 \%$ and from $61.90 \%$ to $64.41 \%$ with an increase in the acid concentration from 0.1 to $0.7 \mathrm{M} \mathrm{H}_{2} \mathrm{SO}_{4}$ at $100^{\circ} \mathrm{C}$ for citronella and bagasse, respectively. The higher $\mathrm{CI}$ value indicates removal of more hemicelluloses leaving the crystalline cellulose fraction intact in the pretreated solid residues. Hence, crystallinity of cellulose was found to increase with increased acid concentrations. Maximum CI of citronella biomass $(56.18 \%)$ and bagasse $(64.41 \%)$ was obtained at $0.7 \mathrm{M}$ and $100^{\circ} \mathrm{C}$. Further, increase in the temperature to $120^{\circ} \mathrm{C}$ decreases CI from $56.18 \%$ to $55.14 \%$ for citronella and from $61.60 \%$ to $60.84 \%$ for bagasse, which indicates either the change in the crystallinity structure of cellulose allomorphs (Cellulose I to Cellulose II) or the disruption of crystalline cellulose structure at higher temperatures (Figure 6). The degradation of hemicellulose and amorphous cellulose occurs at low temperature followed by degradation of crystalline cellulose at higher temperature [54]. The CI of both the biomass types decreased abruptly after enzymatic hydrolysis process, which might be due to the degradation of crystalline cellulose to glucose. The least CI value of enzymatically hydrolysed residual biomass at $50^{\circ} \mathrm{C}, 10 \mathrm{FPU}$, and $72 \mathrm{hr}$ revealed maximum degradation of cellulose; further increase in the temperature to $60^{\circ} \mathrm{C}$ showed only a minimal change in $\mathrm{CI}$ value compared to $50^{\circ} \mathrm{C}$. The minimum CI value for spent citronella biomass and bagasse was found to be $34.16 \%$ and $37.28 \%$, respectively.

SEM analysis results revealed that cells of spent citronella biomass sample were distorted due to extensive thermal stress on the oil glands causing rapid expansion and disruption, thereby releasing the oil content, whereas the untreated sample of bagasse showed intact cell tissues as represented in Figure $7(\mathrm{a})$. The structural changes in the acid treated sample 

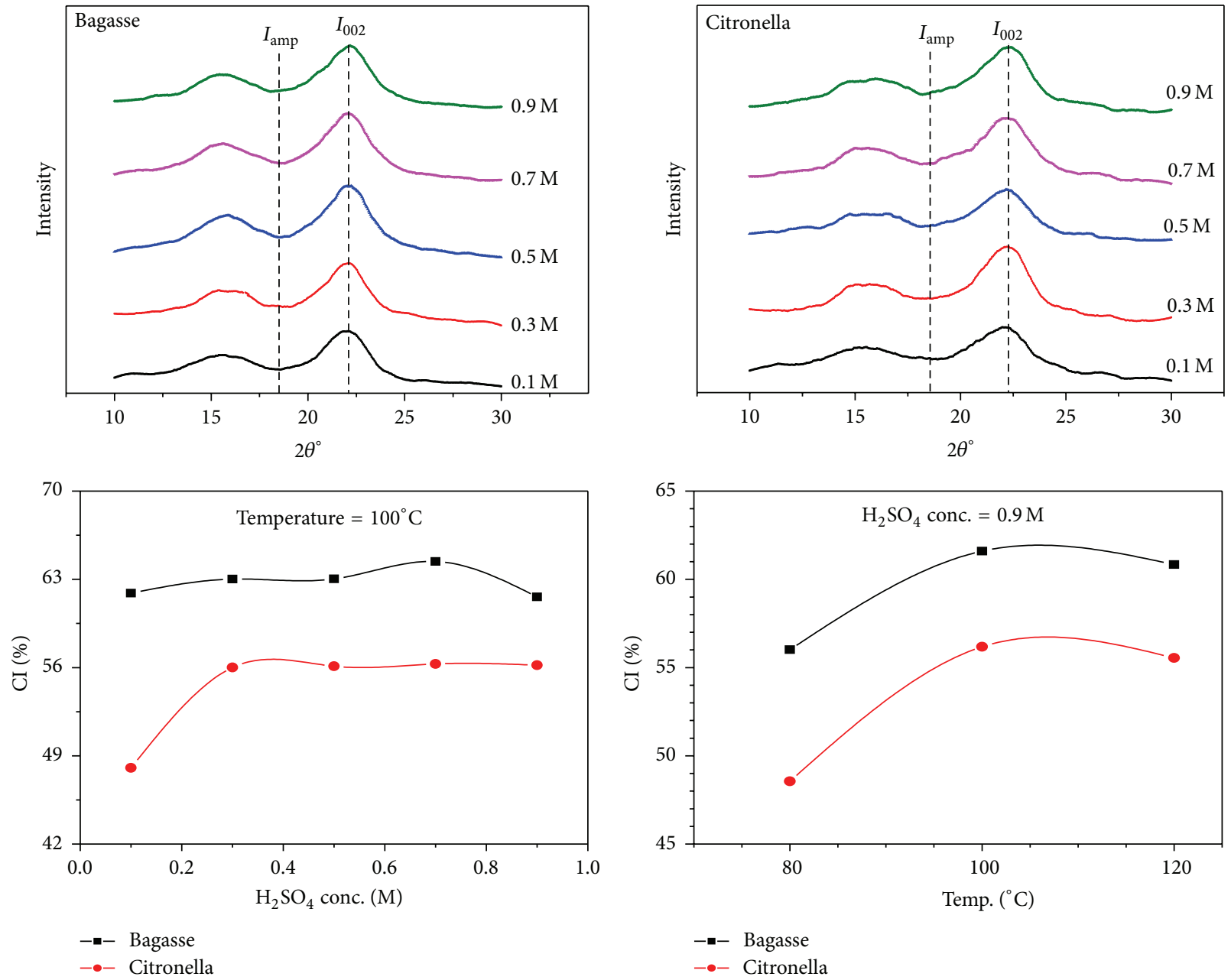

(a)

(b)

FIGURE 6: XRD analysis of acid pretreated biomass at (a) different $\mathrm{H}_{2} \mathrm{SO}_{4}$ concentration at $100^{\circ} \mathrm{C}$ and (b) different temperature at $0.9 \mathrm{M}$ $\mathrm{H}_{2} \mathrm{SO}_{4}$.

in both the biomass types with exposed pores as depicted in Figure 7(b) revealed depolymerization of holocellulose and removal of significant amount of lignin [55]. SEM analysis of enzymatically hydrolysed biomass samples showed insignificant changes in the structure compared to acid pretreated sample.

\section{Conclusions}

In this work, low acid concentration $\left(0.1 \mathrm{M} \mathrm{H}_{2} \mathrm{SO}_{4}\right)$ and higher operating temperature $\left(120^{\circ} \mathrm{C}\right)$ were considered as an optimum condition for acid pretreatment process. At this optimum condition, maximum TRS yield obtained was $71.87 \%$ and $80.75 \%$ for sugarcane bagasse and spent citronella biomass, respectively. In the enzymatic hydrolysis process, CI of spent citronella biomass and bagasse decreased to $34.16 \%$ and $37.28 \%$, respectively, indicating significant conversion of crystalline cellulose to glucose. Considering high sugar yield in the process, dilute acid pretreatment using sulfuric acid could be a good choice for the hydrolysis of spent citronella biomass and sugarcane bagasse.

\section{Competing Interests}

The authors declare that there is no conflict of interests regarding the publication of this paper.

\section{Acknowledgments}

The work reported in this paper was financially supported by a research grant received under Fast Track Scheme from Department of Science and Technology (DST), Government of India (no. SR/FTP/ETA-0018/2010). Authors thankfully acknowledge the Department of Chemical Engineering for providing necessary facilities to carry out this research work and also acknowledge the analytical facilities provided by Center for Instrumentation Facility (CIF) at IIT Guwahati. 

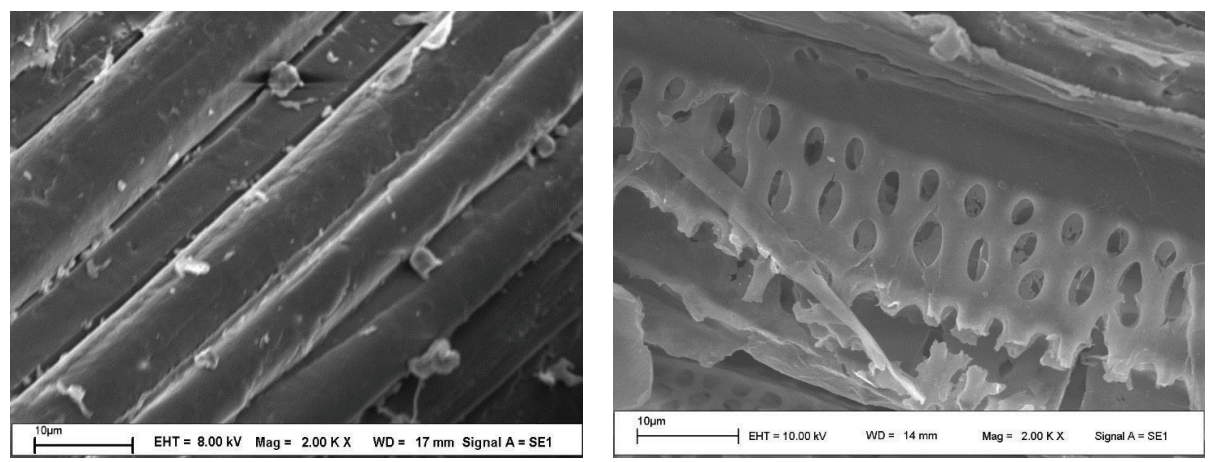

(a)
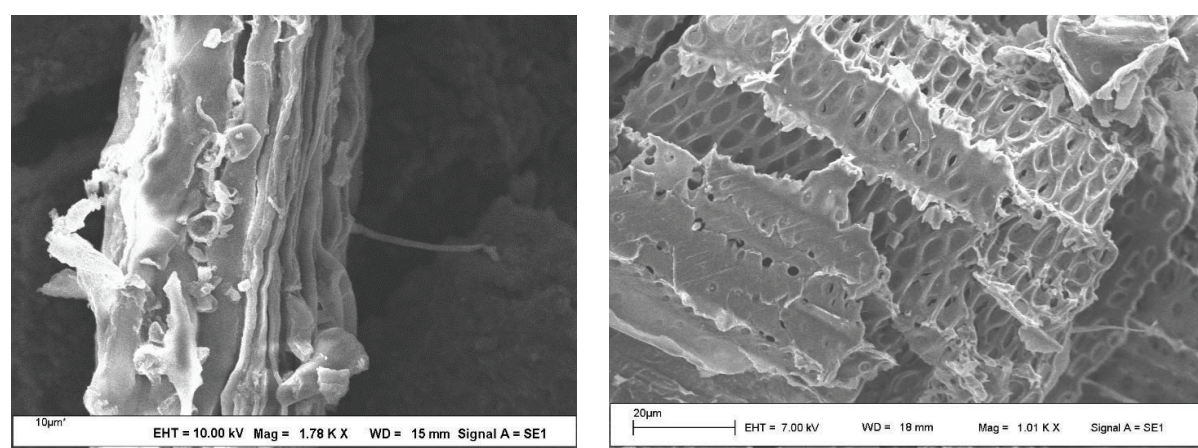

(b)

FIGURE 7: SEM analysis of biomass: (a) before and after acid treatment of bagasse and (b) before and after acid treatment of spent citronella biomass.

\section{References}

[1] World Energy Council, Survey of Energy Resources, Elsevier, Oxford, UK, 20th edition, 2004.

[2] P. K. Rout, A. D. Nannaware, and R. Rajeasekharan, "A process for chemical conversion of cellulose isolated from aromatic spent biomass to hydroxymethyl furfural," WO2013102911A1, 2013.

[3] E. Dorrestijn, L. J. J. Laarhoven, I. W. C. E. Arends, and P. Mulder, "The occurrence and reactivity of phenoxyl linkages in lignin and low rank coal," Journal of Analytical and Applied Pyrolysis, vol. 54, no. 1-2, pp. 153-192, 2000.

[4] C. R. Carere, R. Sparling, N. Cicek, and D. B. Levin, "Third generation biofuels via direct cellulose fermentation," International Journal of Molecular Sciences, vol. 9, no. 7, pp. 1342-1360, 2008.

[5] R. P. Chandra, R. Bura, W. E. Mabee, A. Berlin, X. Pan, and J. N. Saddler, "Substrate pretreatment: the key to effective enzymatic hydrolysis of lignocellulosics?" Advances in Biochemical Engineering/Biotechnology, vol. 108, pp. 67-93, 2007.

[6] C. Rolz, R. Leon, M. C. Arriola, and S. Cabrera, "Biodelignification of lemon grass and citronella bagasse by white-rot fungi," Applied and Environmental Microbiology, vol. 52, no. 4, pp. 607611, 1986.

[7] C. K. Sakdaronnarong, N. Onsrithong, R. Suwankrua, and W. Jonglertjunya, "Improving enzymatic saccharification of sugarcane bagasse by biological/physico-chemical pretreatment using Trametes versicolor and Bacillus sp.", BioResources, vol. 7, no. 3, pp. 3935-3947, 2012.

[8] C. Martín and A. B. Thomsen, "Wet oxidation pretreatment of lignocellulosic residues of sugarcane, rice, cassava and peanuts for ethanol production," Journal of Chemical Technology and Biotechnology, vol. 82, no. 2, pp. 174-181, 2007.

[9] C. Martín, H. B. Klinke, and A. B. Thomsen, "Wet oxidation as a pretreatment method for enhancing the enzymatic convertibility of sugarcane bagasse," Enzyme and Microbial Technology, vol. 40, no. 3, pp. 426-432, 2007.

[10] Y. Sun and J. J. Cheng, "Dilute acid pretreatment of rye straw and bermudagrass for ethanol production," Bioresource Technology, vol. 96, no. 14, pp. 1599-1606, 2005.

[11] T. Jeoh, C. I. Ishizawa, M. F. Davis, M. E. Himmel, W. S. Adney, and D. K. Johnson, "Cellulase digestibility of pretreated biomass is limited by cellulose accessibility," Biotechnology and Bioengineering, vol. 98, no. 1, pp. 112-122, 2007.

[12] N. Kosaric and F. Vardar-Sukan, "Potential source of energy and chemical products," in The Biotechnology of Ethanol: Classical and Future Applications, Wiley-VCH, Weinheim, Germany, 2001.

[13] A. Orozco, M. Ahmad, D. Rooney, and G. Walker, "Dilute acid hydrolysis of cellulose and cellulosic bio-waste using a microwave reactor system," Process Safety and Environmental Protection, vol. 85, no. 5, pp. 446-449, 2007.

[14] M. von Sivers and G. Zacchi, "A techno-economical comparison of three processes for the production of ethanol from pine," Bioresource Technology, vol. 51, no. 1, pp. 43-52, 1995.

[15] C. Luo, D. L. Brink, and H. W. Blanch, "Identification of potential fermentation inhibitors in conversion of hybrid poplar hydrolyzate to ethanol," Biomass and Bioenergy, vol. 22, no. 2, pp. 125-138, 2002.

[16] J. D. McMillan, "Pretreatment of lignocellulosic biomass," in Enzymatic Conversion of Biomass for Fuels Production, vol. 566 
of ACS Symposium Series, pp. 292-324, American Chemical Society, Washington, DC, USA, 1994.

[17] Q. A. Nguyen, M. P. Tucker, F. A. Keller, and F. P. Eddy, "Two-stage dilute-acid pretreatment of softwoods," Applied Biochemistry and Biotechnology, vol. 84-86, pp. 561-576, 2000.

[18] Y. Y. Lee, P. V. Iyer, and R. W. Torget, "Dilute-acid hydrolysis of lignocellulosic biomass," Advances in Biochemical Engineering/Biotechnology, vol. 65, pp. 93-115, 1999.

[19] N. Mosier, C. E. Wyman, B. E. Dale et al., "Features of promising technologies for pretreatment of lignocellulosic biomass," Bioresource Technology, vol. 96, no. 6, pp. 673-686, 2005.

[20] R. W. Torget, M. Himmel, and K. Grohmann, "Dilute-acid pretreatment of two short-rotation herbaceous crops-scientific note," Applied Biochemistry and Biotechnology, vol. 34-35, no. 1, pp. 115-123, 1992.

[21] A. Sluiter, B. Hames, R. Ruiz, C. Scarlata, J. Sluiter, and D. Templeton, Determination of Extractives in Biomass, National Renewable Energy Laboratory, Golden, Colo, USA, 2008.

[22] S. N. Naik, V. V. Goud, P. K. Rout, K. Jacobson, and A. K. Dalai, "Characterization of Canadian biomass for alternative renewable biofuel," Renewable Energy, vol. 35, no. 8, pp. 1624$1631,2010$.

[23] S. Sasmal, V. V. Goud, and K. Mohanty, "Characterization of biomasses available in the region of North-East India for production of biofuels," Biomass and Bioenergy, vol. 45, pp. 212220, 2012.

[24] R. D. O. Moutta, V. S. Ferreira-Leitão, and E. P. D. S. Bon, "Enzymatic hydrolysis of sugarcane bagasse and straw mixtures pretreated with diluted acid," Biocatalysis and Biotransformation, vol. 32, no. 1, pp. 93-100, 2014.

[25] R. O. Moutta, A. K. Chandel, R. C. L. B. Rodrigues, M. B. Silva, G. J. M. Rocha, and S. S. Silva, "Statistical optimization of sugarcane leaves hydrolysis into simple sugars by dilute sulfuric acid catalyzed process," Sugar Tech, vol. 14, no. 1, pp. 53-60, 2012.

[26] A. K. Chandel, R. K. Kapoor, A. Singh, and R. C. Kuhad, "Detoxification of sugarcane bagasse hydrolysate improves ethanol production by Candida shehatae NCIM 3501," Bioresource Technology, vol. 98, no. 10, pp. 1947-1950, 2007.

[27] S. Pattra, S. Sangyoka, M. Boonmee, and A. Reungsang, "Biohydrogen production from the fermentation of sugarcane bagasse hydrolysate by Clostridium butyricum," International Journal of Hydrogen Energy, vol. 33, no. 19, pp. 5256-5265, 2008.

[28] G. J. V. Betancur and N. Pereira Jr., "Sugar cane bagasse as feedstock for second generation ethanol production. Part I: diluted acid pretreatment optimization," Electronic Journal of Biotechnology, vol. 13, no. 3, 2010.

[29] R. Aguilar, J. A. Ramírez, G. Garrote, and M. Vázquez, "Kinetic study of the acid hydrolysis of sugar cane bagasse," Journal of Food Engineering, vol. 55, no. 4, pp. 309-318, 2002.

[30] W. Jonglertjunya, W. Makkhanon, T. Siwanta, and P. Prayoonyong, "Dilute acid hydrolysis of sugarcane bagasse for butanol fermentation," Chiang Mai Journal of Science, vol. 41, no. 1, pp. 60-70, 2014.

[31] L.-Q. Jiang, Z. Fang, X.-K. Li, J. Luo, and S.-P. Fan, “Combination of dilute acid and ionic liquid pretreatments of sugarcane bagasse for glucose by enzymatic hydrolysis," Process Biochemistry, vol. 48, no. 12, pp. 1942-1946, 2013.

[32] R. G. Candido, G. G. Godov, and A. R. Goncalves, "Study of sugarcane bagasse pretreatment with sulfuric acid as a step of cellulose obtaining," International Journal of Biological, Biomolecular, Agricultural, Food and Biotechnological Engineering, vol. 6, no. 1, pp. 6-10, 2012.
[33] R. Sindhu, M. Kuttiraja, P. Binod, K. U. Janu, R. K. Sukumaran, and A. Pandey, "Dilute acid pretreatment and enzymatic saccharification of sugarcane tops for bioethanol production," Bioresource Technology, vol. 102, no. 23, pp. 10915-10921, 2011.

[34] B. C. Saha, L. B. Iten, M. A. Cotta, and Y. V. Wu, "Dilute acid pretreatment, enzymatic saccharification, and fermentation of rice hulls to ethanol," Biotechnology Progress, vol. 21, no. 3, pp. 816-822, 2005.

[35] S. Ledakowicz and P. Stolarek, "Kinetics of biomass thermal decomposition," Chemical Papers, vol. 56, no. 6, pp. 378-381, 2002.

[36] A. Saddawi, J. M. Jones, A. Williams, and M. A. Wójtowicz, "Kinetics of the thermal decomposition of biomass," Energy and Fuels, vol. 24, no. 2, pp. 1274-1282, 2010.

[37] M. Carrier, A. Loppinet-Serani, D. Denux et al., "Thermogravimetric analysis as a new method to determine the lignocellulosic composition of biomass," Biomass and Bioenergy, vol. 35, no. 1, pp. 298-307, 2011.

[38] G. L. Miller, "Use of dinitrosalicylic acid reagent for determination of reducing sugar," Analytical Chemistry, vol. 31, no. 3, pp. 426-428, 1959.

[39] H. Hoseinpour, K. Karimi, H. Zilouei, and M. J. Taherzadeh, "Simultaneous pretreatment of lignocellulose and hydrolysis of starch in mixtures to sugars," BioResources, vol. 5, no. 4, pp. 2457-2469, 2010.

[40] M. Ioelovich and E. Morag, "Study of enzymatic hydrolysis of pretreated biomass at increased solid loadings," BioResources, vol. 7, no. 4, pp. 4672-4682, 2012.

[41] R. Timung, M. Mohan, B. Chilukoti, S. Sasmal, T. Banerjee, and V. V. Goud, "Optimization of dilute acid and hot water pretreatment of different lignocellulosic biomass: a comparative study," Biomass and Bioenergy, vol. 81, pp. 9-18, 2015.

[42] S. Abdullah, S. Yusup, M. Ahmad, and L. Ramli, “Thermogravimetry study on pyrolysis of various lignocellulosic biomass for potential hydrogen production," International Journal of Biomedical Engineering and Technology, vol. 3, no. 12, pp. 137141, 2010.

[43] M. J. Taherzadeh and K. Karimi, "Acid-based hydrolysis processes for ethanol from lignocellulosic materials: a review," BioResources, vol. 2, no. 3, pp. 472-499, 2007.

[44] G. Gonzales, S. J. Lopes, G. Caminal, and C. Sola, "Dilute acid hydrolysis of wheat straw hemicellulose at moderate temperature: a simplified kinetic model," Biotechnology and Bioengineering, vol. 28, no. 2, pp. 288-293, 1986.

[45] T. Ezeji, N. Qureshi, and H. P. Blaschek, "Butanol production from agricultural residues: impact of degradation products on Clostridium beijerinckii growth and butanol fermentation," Biotechnology and Bioengineering, vol. 97, no. 6, pp. 1460-1469, 2007.

[46] M. G. O. Ogawa, Y. U. Ishida, and U. Naoto, "Ethanol production from the water hyacinth Eichhornia crassipes by yeast isolated from various hydrospheres," African Journal of Microbiology Research, vol. 2, pp. 110-113, 2008.

[47] K. Rajan and D. J. Carrier, "Effect of dilute acid pretreatment conditions and washing on the production of inhibitors and on recovery of sugars during wheat straw enzymatic hydrolysis," Biomass and Bioenergy, vol. 62, pp. 222-27, 2014.

[48] A. M. J. Kootstra, H. H. Beeftink, E. L. Scott, and J. P. M. Sanders, "Comparison of dilute mineral and organic acid pretreatment for enzymatic hydrolysis of wheat straw," Biochemical Engineering Journal, vol. 46, no. 2, pp. 126-131, 2009. 
[49] M. Idrees, A. Adnan, S. A. Bokhari, and F. A. Qureshi, "Production of fermentable sugars by combined chemo-enzymatic hydrolysis of cellulosic material for bioethanol production," Brazilian Journal of Chemical Engineering, vol. 31, no. 2, pp. 355363, 2014.

[50] E. Palmqvist and B. Hahn-Hägerdal, "Fermentation of lignocellulosic hydrolysates. II: inhibitors and mechanisms of inhibition," Bioresource Technology, vol. 74, no. 1, pp. 25-33, 2000.

[51] B. C. Saha, L. B. Iten, M. A. Cotta, and Y. V. Wu, "Dilute acid pretreatment, enzymatic saccharification and fermentation of wheat straw to ethanol," Process Biochemistry, vol. 40, no. 12, pp. 3693-3700, 2005.

[52] H. A. Fileto-Pèrez, J. G. Rutiaga-Quiñones, C. N. AguilarGonzález, J. B. Páez, J. López, and O. M. Rutiaga-Quiñones, "Evaluation of Eichhornia crassipes as an alternative raw material for reducing sugars production," BioResources, vol. 8, no. 4, pp. 5340-5348, 2013.

[53] R. S. Prakasham, D. Nagaiah, K. S. Vinutha et al., "Sorghum biomass: a novel renewable carbon source for industrial bioproducts," Biofuels, vol. 5, no. 2, pp. 159-174, 2014.

[54] E. Quintana, C. Valls, A. G. Barneto, T. Vidal, J. Ariza, and M. B. Roncero, "Studying the effects of laccase treatment in a softwood dissolving pulp: cellulose reactivity and crystallinity," Carbohydrate Polymers, vol. 119, pp. 53-61, 2015.

[55] E. C. Giese, M. Pierozzi, K. J. Dussán, A. K. Chandel, and S. S. Da Silva, "Enzymatic saccharification of acid-alkali pretreated sugarcane bagasse using commercial enzyme preparations," Journal of Chemical Technology and Biotechnology, vol. 88, no. 7, pp. 1266-1272, 2013. 

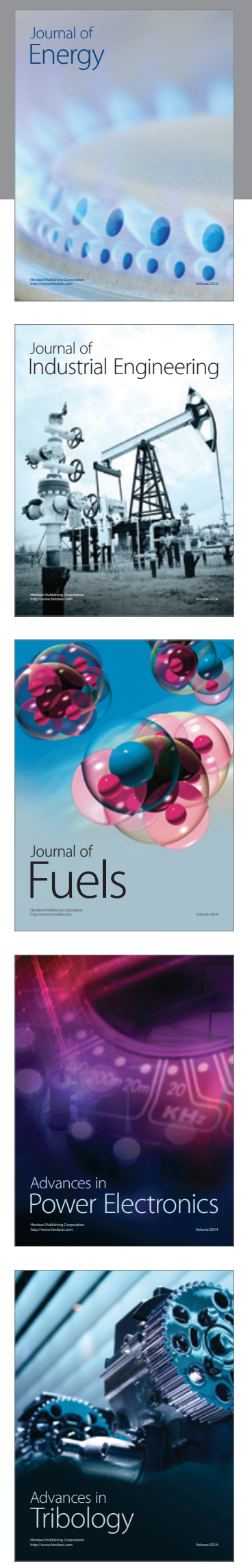
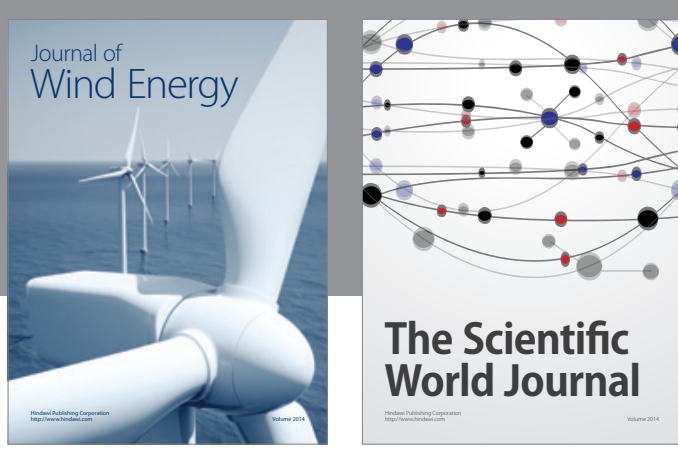

The Scientific World Journal
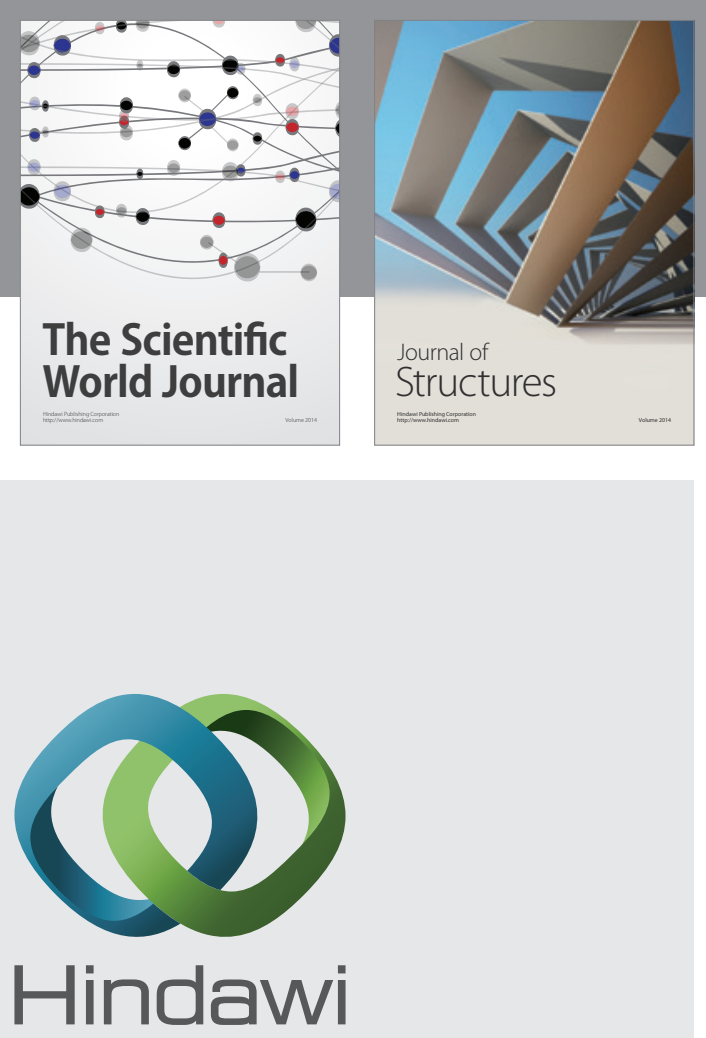

Submit your manuscripts at

http://www.hindawi.com
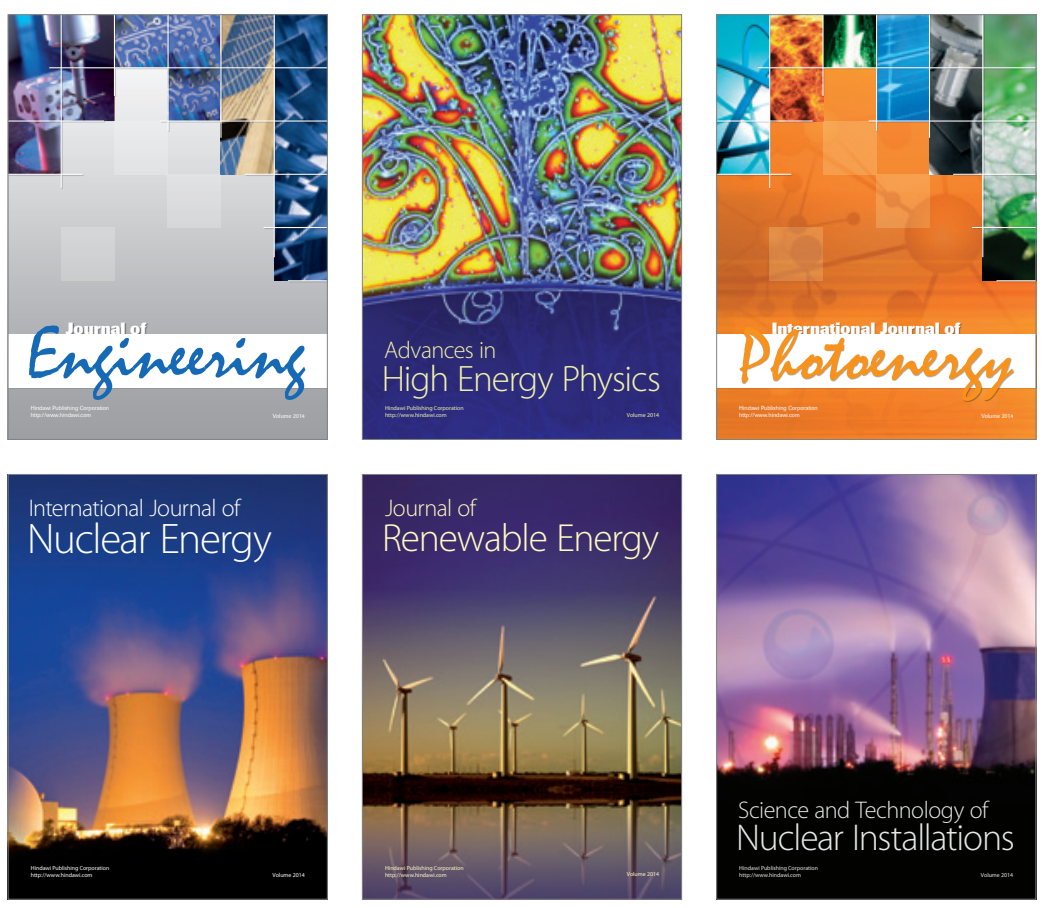
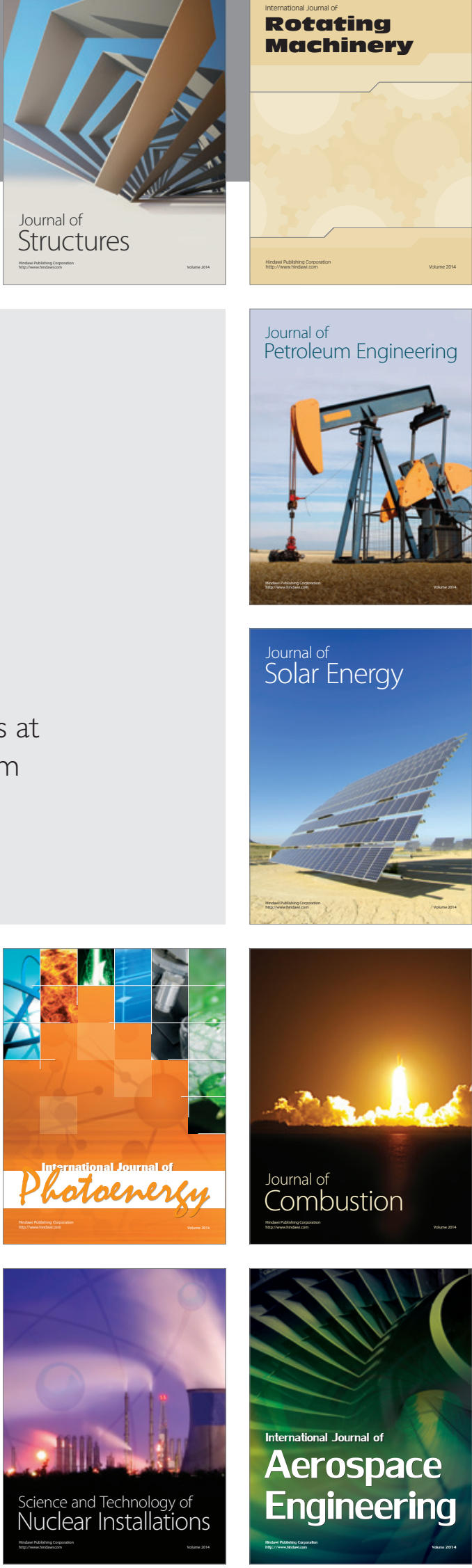